STock (Abstract, 1923).-Zentralbl.ges. Ophthal., Vol. X, p. 100.

Strau B (1892). -Ophthal. Rev., Vol. XI, p. 97.

STREBEL (1921). -Schweiz. med. Wschr., Vol. LI, p. 1138.

- (Abstract, 1921).-Ophthal. Yearbook, Vol. XIX, p. 36.

Stutterheim (1932).-Brit. Jl. Ophthal., Vol XVI, p. 20.

(1933).-Brit. Jl. Ophthal., Vol. XVII, p. 394.

SwaB (1930) - Amer. Jl. Ophthal., Vol. XIII, p. 1054.

TALBotT (1929).-Calif. West. Med., Vol. XXX, p. 100.

TAYLOR (1932).-Jl. Iou a St. Med. Soc., Vol. XXII, p. 267.

THORNE (1930).-Milit. Surg., Vol. LXVI, p. 175.

Thomson (1924).-Trans. Ophthal. Soc. U.K., Vol. XLIV, p. 239.

TSCHERNING (1920).-_" Physiologic Optics," Philadelphia.

VALK (1912).-Ophthal Rec., Vol. XXI, p. 639.

VAN DER HOEve (1932).-Trans. Ophthal. Soc. U.K., Vol. LII, p. 1.

VERHOEFF (1899). - Johns Hopkins Hosp. Bull., Vol. X, p. 87.

- (Reprint, 1899).--Trans. A mer. Ophthal. Soc, Vol. ViII, p. 490

(Reprint, 1926).-Amer. Jl. Physiol. Opt., Vol. VII, p. 39.

VON DER HEYD' (1918). - Illinois Med. Jl., Vol. XXXIII, p. 329.

WALTER (1916).-Arch. Ophthal. N.Y., Vol. XLV, p. 172.

WELLS (1926).- " The Stereoscope in Ophthalmology," Boston.

Weymouth (1916).-Ophthal. Rec. N.Y., Vol. XXV, p. 271.

White (1936a).-Amer. Jl. Ophthal., Vol. XIX, p. 653.

- (1936b).-I'Pnn. Med. Jl., Vol. XXXIX, p. 943.

WhitNall (1921).- - The Anatomy of the Human Orbit," London.

Whittingham (1940).--Jl. R. Nav. Med. Serv., Vol. XXVI, p. 15.

Williams (1901).-Trans. Amer Ophthal. Soc, Vol. IX, p. 388.

- (Abstract, 1904).-Ophthal. Rec., Vol. XIII, p. 334.

Woods (1920).--Sth. Med. Jl., Vol. XIII, p. 126.

(Astract, 1919).-Ji. Amer. Med. A ssoc., Vol. LXXIII, p. 1795.

WraY (1912).-Trans. Ophthal. Soc. U.K., Vol. XXXII, p. 162.

Young (1926a).-Virginia Med. Mon., Vol. LIII, p. 25.

(Abstract, 1927).-Ophthal. Yearbook, Vol. XXIII, p. 51.

(1926b).-Virginia Med. Mon., Vol. LiII, p. 233.

YULE and KENDALL (1937).- " An Introduction to the Theory of Statistics," London.

ZentmaYer (1911).--Trans. Amer. Ophthal. Soc., Vol. XIII, p 521.

\title{
SURGICAL CURE OF AN UNUSUAL DETACHMENT OF THE RETINA
}

BY

\author{
E. C. ZoraB \\ R.A.M.C.
}

THE following case is reported here so that the somewhat remarkable cure effected by Professor Weve, of Utrecht, should not go unrecorded.

The Rev. G.E.Q., aged 42 years, was seen by Mr. Freeman Heal, of Luton, in September, 1939, for routine change of spectacles. He was a high myope, but with correction could see $6 / 9$ with the right eye. The sight of the left eye had been lost many years before as the result of a detached retina. Three weeks later, without any trauma, his sight suddenly failed when a large shadow came across it from left to right. He went back next day to Mr. Freeman Heal 
who diagnosed retinal detachment, and sent him up to Moorfields Eye Hospital, where he was admitted. His condition then was:-

Right eye :-No injection. Cornea, iris, and anterior chamber normal. Lens clear. Some vitreous haze. Large para-oral retinal tear extending from 6 o'clock right round the temporal retina to one o'clock. A fringe of torn edge of retina could just be seen around the ora serrata, but the main part of the retina was folded over on itself towards the nasal side. The only attached part of retina to be seen was a thin strip down the nasal periphery. For the rest all that could be seen was either choroid or posterior surface retina. Vision was only perception of light, with hand movements in the extreme temporal periphery. The macula was detached and the retina rolled back like a carpet so that its attachment at the disc edge could just be seen. Tension was normal.

Left eye:-Phthisis bulbi. Vision=no perception of light.

With such an extensive tear and detachment the prospect of cure was deemed too small to justify advising an operation. The patient, however, was anxious to take a chance however small it might be, for the alternative was obviously total blindness. A brief description of the case was cabled to Professor Weve in Utrecht, who agreed to take over the case if he could be sent there. With the co-operation of the Foreign Office and Dutch Air Lines all arrangements were made in two days, and he was flown to Utrecht. He was kept in bed there for three days lying on the affected side, and was then operated on in the same position by the usual Weve technique. The retina was sealed down by this one operation and he was back in London again in under six weeks. At that time his corrected vision was $5 / 60$. There was marked vitreous haze with some floating strands. Good reaction was seen all along the length of the tear. The retina everywhere was flat back in place. During the course of the next two months the vitreous cleared considerably and the vision improved to 6/36 (one letter). He was then allowed to go back to his work, for which he could see just enough, but was given the usual precautionary instructions. It is now just over a year since his operation and Mr. Freeman Heal, who saw him on December 20, 1940, reports as follows:-

Right eye:-Vision with $-10^{\circ} 0$ D.sph. -3.5 D.cyl. $180^{\circ}=6 / 36$. J. 6 at $13 \mathrm{cms}$. and J.1 at $10 \mathrm{cms}$.

The iris is atrophic in patches. There is a band of posterior synechia below, and one or two smaller ones above, so that the pupil is heart-shaped when dilated. There is a faint filmy granular coating on the anterior lens capsule. The lens is free from cataract. The vitreous body is degenerate, but the floating opacities and fibrinous skeins are very much less evident than they were a few months ago. There is a small myopic crescent, but no marked myopic changes. The disc is clear cut and of good colour. The 
macular region appears normal. At the periphery of the fundus extending from " six o'clock below temporally and superiorly to two o'clock" above there is a white band of choroidal scarring some two D.D. wide situated about two D.D. behind the ora. There is considerable pigmentation of this band in the lower temporal quadrant, but little elsewhere. Over the remainder of the periphery the fundus appears normal.

The patient is able to carry on his duties as a priest. A long. letter he has written shows no evidence of visual inability.

\title{
Summary
}

The main features of the case are:-

1. The large size of the tear; more than half the circumference of the retina.

2. The folding in half of the detached retina so that its posterior surface was facing anteriorly.

3. The replacement of the retina by ordinary operation, assisted perhaps by gravity, but not by retinal hooks or other devices.

4. The degree of recovery of vision after complete and wide separation of the macula for over a week.

My thanks are due to Mr. Freeman Heal for his examination notes, and for his permission to publish this case; to Mr. Shapland, under whose care the case was admitted to Moorfields, for permission to send the patient to Utrecht; and lastly to Professor Weve for his notes and diagrams of the operation, and for its successful result.

\section{A NEW DARK ADAPTATION TESTER}

\author{
BY \\ SIMON YUDKIN \\ FROM THE DEPARTMENT OF PATHOLOGY, UNIVERSITY \\ COLLEGE HOSPITAL, LONDON
}

IN view of the importance of night-blindness in present circum. stances it is felt that the following description of an instrument which combines many advantages with comparative simplicity may be of some use.

The dark adaptation tester* as devised by R. T. M. Haines (1) and investigated and used by the writer, is an instrument designed to test the rate at which the eye recovers its power to distinguish a faintly lighted object following a period in which it has been subjected to strong illumination, and also to discover the threshold of visibility after complete adaptation.

* Manufactured by Crookes' Laboratories, London. 